\title{
RESEARCH ARTICLE \\ Methicillin-resistant Staphylococcus aureus in milk from dairy cows with chronic mastitis
}

\author{
Hayriye Yeşim $\operatorname{Can}^{1 *}$, Mehmet Elmalı ${ }^{1}$, Yaşar Ergün ${ }^{2}$ \\ ${ }^{1}$ Department of Food Hygiene and Technology, Faculty of Veterinary Medicine, Mustafa Kemal University, Hatay, 31060, Turkey, \\ ${ }^{2}$ Department of Obstetrics and Gynaecology, Faculty of Veterinary Medicine, Mustafa Kemal University, Hatay, 31060, Turkey \\ Geliş:10.05.2017, Kabul: 08.09.2017 \\ *yesimcan@mku.edu.tr
}

\section{Kronik mastitli inek sütlerinde metisiline dirençli Staphylococcus aureus}

Eurasian J Vet Sci, 2017, 33, 4, 255-259

DOI:10.15312/EurasianJVetSci.2017.169

Öz

Amaç: Bu çalışmanın amaçları: i) sürekli tekrarlayan mastitli inek sütlerinden koagulaz pozitif stafilokok ve koagulaz negatif stafilokokları izole etmek, ii) izolatları Staphylococcus spp., Staphylococcus aureus ve metisiline dirençli Staphylococcus aureus yönünden multipleks PCR yöntemi ile doğrulamak ve iii) disk difüzyon yöntemi ile izolatların antimikrobiyel duyarlılığını belirlemektir.

Gereç ve Yöntem: Bu kapsamda, Hatay ilinde sürekli tekrarlayan klinik mastit sorunu yaşayan süt ineklerinden toplam 52 adet süt örneği alındı. Koagulaz pozitif stafilokok ve koagulaz negatif stafilokokların izolasyon ve identifikasyonu klasik kültür tekniği ile yapıldı. Koagulaz pozitif stafilokok ve koagulaz negatif stafilokok olarak saptanan izolatların hepsi $16 S$ rRNA, nuc ve mecA gen sekansları baz alınarak, sirasıly Staphylococcus spp., $S$. aureus ve metisiline dirençli $S$. aureus yönünden multipleks PCR yöntemi ile doğrulandı. Ayrıca izolatların antimikrobiyel duyarlılığı araştırıldı.

Bulgular: Süt örneklerinin \% 48.0'inde pozitif sonuçlar elde edildi. Pozitif örneklerden toplam 56 adet stafilokok izolatı $(22$ adet koagulaz pozitif stafilokok ve 34 adet koagulaz negatif stafilokok) elde edildi. Koagulaz pozitif stafilokok izolatlarının 20'si (\% 90.9) S. aureus olarak doğruland. S. aureus olarak doğrulanan izolatlarının 18 'inde (\% 90) mecA geni tespit edildi. Ayrıca, bu çalışmada izolatlarda disk difüzyon yöntemiyle, eritromisin $(\% 66)$, tetrasiklin (\% 62.5), ampisilin $(\% 60.7)$, penisilin $(\%$ 60.7), sefoksitin (\% 50), oksasilin (\% 46.4) ve kloramfenikole (\% 5.3) karşı direnç belirlendi.

Öneri: Çalışmada, kronik tekrarlayan mastitli inek sütlerinde antibiyotiklere dirençli stafilokokların ve özellikle metisiline dirençli $S$. aureus'un saptanması, bu bakterilerin süt ile birlikte gıda zinciri boyunca yayılma olasılığı açısından dikkate alınmalidır.

Anahtar kelimeler: Koagulaz, mastit, mecA, süt, Staphylococcus
Abstract

Aim: The aims of this study were: i) to isolate coagulase positive Staphylococcus (CPS) and coagulase-negative Staphylococcus (CNS) in milk from dairy cows with chronic recurrent mastitis, ii) to verify isolates in terms of Staphylococcus spp., Staphylococcus aureus and methicillin-resistant Staphylococcus aureus (MRSA) by multiplex PCR, and iii) to determine the antimicrobial susceptibility of the isolates by disk diffusion method.

Materials and Methods: A total of 52 milk samples were collected from the dairy cows with chronic recurrent mastitis in Hatay province. Isolation and identification of CPS and CNS were detected by using classical culture method. All CPS and CNS isolates were investigated for antimicrobial susceptibility and also, were confirmed as Staphylococcus spp., S. aureus and MRSA by multiplex PCR based on $16 S$ rRNA, nuc, and mecA gene sequences, respectively.

Results: Positive results were found in $48.0 \%$ of the milk samp-les. A total of 56 Staphylococcus spp. isolates (22 CPS and $34 \mathrm{CNS}$ ) were obtained from the positive samples. Twenty (90.9\%) of the CPS isolates were detected as S. aureus. The mecA gene was detected in 18 (90\%) of the $S$. aureus isolates. By disk dif-fusion method, resistance to erythromycin (66\%), tetracycli-ne (62.5\%), ampicillin (60.7\%), penicillin (60.7\%), cefoxitin (50\%), oxacillin (46.4\%), and chloramphenicol (5.3\%) was also determined in this study.

Conclusion: In the study, the detection of antibiotic resistant Staphylococcus strains and especially MRSA in milk from dairy cows with chronic recurrent mastitis should be taken into account for potential spread through the dairy food chain.

Keywords: Coagulase, mastitis, mecA, milk, Staphylococcus 


\section{Introduction}

Mastitis is one of the most common diseases that reduces milk production and causes serious economic losses in dairy cattle. Bovine mastitis is generally classified as follows: "subclinical mastitis," when infected cows had no clinically symptoms and normal milk appearance; "clinical mastitis," when infected cows had clinically symptoms and visible abnormalities in the milk and the udder (Costa et al 2000, Sawant et al 2009, Persson et al 2011).

Staphylococci are the bacteria most commonly isolated from bovine mastitis. Depending on the coagulase ability, staphylococci are divided into two groups known as coagulase-positive Staphylococcus (CPS) and coagulase-negative Staphylococcus (CNS), which is important for considering the diagnosis and treatment of mastitis. Although some strains of Staphylococcus aureus are coagulase-negative, S. aureus generally has coagulase activity and causes clinical and subclinical mastitis. However, CNS are usually isolated from subclinical mastitis in dairy cattle (Martins and Cunha 2007, Taponen and Pyörälä 2009). Antimicrobials are commonly used both for the treatment and control of mastitis in dairy farms. One of the most important problems arising from inappropriate and random use of antimicrobials on dairy farms is the increasing antimicrobial resistance among pathogenic bacteria. Also, transfer of antimicrobial resistance genes between staphylococcal species could lead to chronic recurrent mastitis and in this case it may be difficult to treat mastitis (Costa et al 2000, Virdis et al 2010, Sampimon et al 2011, Ergün et al 2012, Zdolec et al 2016). So, multiple antibiotic resistant strains, and especially methicillin resistant $S$. aureus (MRSA) which is recognized as important nosocomial pathogen, can be spread through the dairy food chain and may pose a risk for human health.

Therefore, this study was conducted to investigate the presence of coagulase-positive Staphylococcus (CPS) and coagulasenegative Staphylococcus (CNS) in milk from dairy cows with chronic recurrent mastitis and to detect methicillin-resistant Staphylococcus aureus (MRSA) by PCR.

\section{Materials and Methods}

In this study, a total of 52 milk samples were obtained from dairy cows suffering from chronic mastitis problem in Hatay province. At the sampling stage, milk samples were taken according to the last one-year farm data, infirmary records, and recurrent California Mastitis Test (CMT) positivity on the same quarter. Milk samples were aseptically collected for microbiological analysis according to the standard protocol of International Dairy Federation (IDF, 1985). Samples were transported on ice to the laboratory and analyzed on the same day.
For microbiological analysis, $10 \mathrm{~mL}$ of each milk sample was taken into a sterile plastic bag. Ninety $\mathrm{mL}$ of sterile $0.1 \%$ peptone water was added onto the sample and then the mixture was homogenized. Decimal dilutions were prepared with using this homogenate and peptone water prepared in 9 $\mathrm{mL}$ of sterile tubes. As a positive control, S. aureus ATCC 43300 (methicillin-resistant strain) was used in the study. Inoculations were done according to spreading plate technique on Baird Parker Agar with Egg Yolk Tellurite Emulsion (BP, Oxoid, CM0275; Egg Yolk Tellurite-Emulsion, Oxoid, SR0054) and incubated for $24-48 \mathrm{~h}$ at $37^{\circ} \mathrm{C}$ in aerobic conditions. At the end of the incubation, up to five typical and/or atypical colonies were selected. The selected colonies were stored in glycerinated Brain Heart Infusion (BHI) broths at $-20^{\circ} \mathrm{C}$ for further analysis.

For coagulase test, frozen colonies were suspended in tubes containing 4-5 mL of BHI broth (Oxoid, CM0225). Broth cultures were incubated for $18-24 \mathrm{~h}$ at $37^{\circ} \mathrm{C}$ in aerobic conditions. Tube coagulase test was performed with using lyophilized-EDTA rabbit plasma (Lyophilized Coagulase Rabbit Plasma with EDTA, Oxoid, R21060). As a result of the coagulase test, positively detected colonies were recorded as coagulase positive Staphylococcus, while negative ones were recorded as coagulase negative Staphylococcus (Bennett and Lancette 1998).

For DNA extraction from the isolates, commercially available bacterial DNA extraction kit (Nucleic Acid Extraction Kit, GF-1, Vivantis, Malaysia) was used and extracted DNAs were stored at $-20^{\circ} \mathrm{C}$. All coagulase positive and coagulase negative isolates were confirmed as Staphylococcus, S. aureus and MRSA by multiplex PCR based on $16 S$ rRNA, nuc, and mecA gene sequences, respectively. Specific primers (Ella Biotech GmbH, Martinsried, Germany) described by Brakstad et al. (1992), Mehrotra et al (2000), Monday and Bohach (1999) were used in this study. For the PCR, ready-to-use PCR Master Mix (PCR Master Mix, 2X, Promega, USA) was used and reaction mix was prepared in a total volume of $25 \mu \mathrm{L}$ contained $0.6 \mu \mathrm{L}$ of each primer. Template DNA was added to the mix as $4 \mu \mathrm{L}$. Multiplex PCR amplification (Mehrotra et al 2000, Keyvan and Özdemir 2016) was carried out under these reaction conditions: pre-denaturation for $4 \mathrm{~min}$ at $94^{\circ} \mathrm{C}, 35$ cycles of denaturation for $30 \mathrm{sec}$ at $94^{\circ} \mathrm{C}$, annealing for $30 \mathrm{sec}$ at $57.5^{\circ} \mathrm{C}$, extension for $40 \mathrm{sec}$ at $72^{\circ} \mathrm{C}$, and then, additional extension for $10 \mathrm{~min}$ at $70^{\circ} \mathrm{C}$. Amplicons were run at $100 \mathrm{~V}$ for 50 min with $1.5 \%$ agarose gel. Genes-specific DNA bands were evaluated under UV light on a gel imaging device (UVP, Upland, USA).

In the study, also, disk diffusion test was used for determination of antimicrobial susceptibility of all coagulase positive and coagulase negative isolates. The antibiotic discs were selected in line with the recommendation of Clinical and Laboratory Standards Institute (CLSI, 2015) and included 


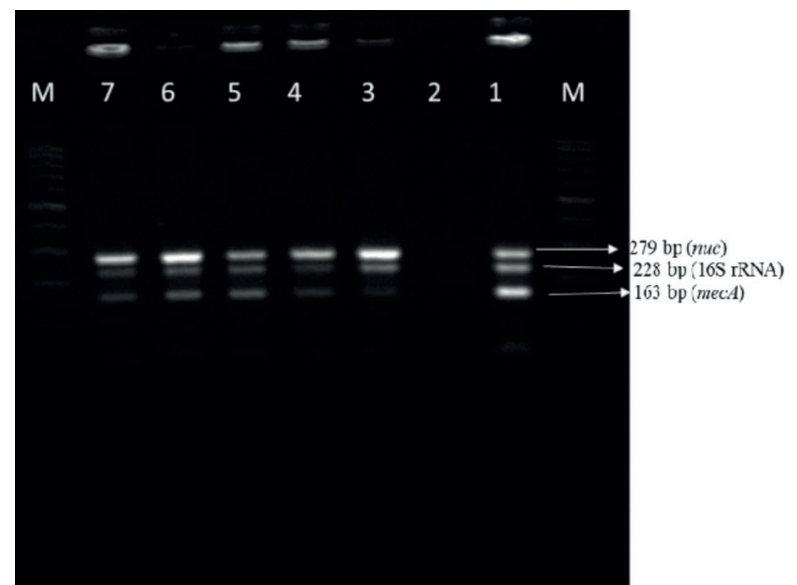

Figure 1. Electrophorese image of the isolates [M: $100 \mathrm{bp}$ DNA marker, 1: Positive control(S. aureus ATCC 43300), 2: Negative control, 3-7: mecA positive isolates (MRSA)]

penicillin, oxacillin, tetracycline, gentamicin, ampicillin, vancomycin, cefoxitin, chloramphenicol, erythromycin, and ciprofloxacin. For disk diffusion test, the cryopreserved isolates were enriched in tubes containing 4-5 mL BHI broths. Then, broth cultures were incubated at $37^{\circ} \mathrm{C}$ until the turbidity of broth culture reached to the $0.5 \mathrm{McF}$ arland standards. After setting the turbidity of broth culture, steril cotton swab was dipped into broth, drained on the wall of tube, and the inoculum was streaked on Mueller-Hinton agar (Oxoid, CM0337). The antibiotic discs were placed on the agar surface in such a way that the distance between the centers of antibiotic discs no closer than $24 \mathrm{~mm}$ and a maximum of 10 disks on a $150-\mathrm{mm}$ plate. Then, the plates were incubated at $37^{\circ} \mathrm{C}$ for $24 \mathrm{~h}$. At the end of the incubation, the diameter of the inhibition zones around the discs was evaluated according to CLSI (2015).

\section{Results}

During the study period, a total of 52 milk samples obtained from the dairy cows with chronic recurrent mastitis in Hatay province were investigated. Positive results were found in $48.0 \%$ of the milk samples, while $51.9 \%$ of them were microbiologically negative. From the 25 positive samples, a total of 56 Staphylococcus spp. isolates (22 CPS and 34 CNS) were obtained. When all CPS and CNS isolates were tested for S. aureus and MRSA by multiplex PCR, 20 (90.9\%) of the CPS isolates were detected as $S$. aureus and mecA gene was detected in $18(90 \%)$ of them. In this study, coagulase-negative $S$. aureus was not found and also, mecA gene was not detected in any CNS isolates.

When the overall antimicrobial susceptibility profiles of the isolates (CPS and CNS) were evaluated, resistance to erythromycin (66\%), tetracycline (62.5\%), ampicillin (60.7\%), penicillin $(60.7 \%)$, cefoxitin (50\%), oxacillin $(46.4 \%)$, and chloramphenicol (5.3\%) was detected. All CPS and CNS were susceptible $(100 \%)$ to vancomycin, gentamicin and ciprofloxacin. Twenty-two (64.7\%) CNS isolates were resistant to one or more antimicrobials. Fifteen $(44.1 \%)$ of the CNS isolates showed multidrug resistance (i.e., resistant to 2 or more antimicrobials). All CPS isolates were resistant to six tested antimicrobials at the same time. The antimicrobial susceptibility of the isolates are shown in Table 1 .

\section{Discussion}

S. aureus and CNS were the mainly isolated bacteria from dairy cows with mastitis (Pitkälä et al 2004, Tenhagen et al 2006) and microbiologically negative findings were also reported in some researches (Kalmus et al 2011, Persson et al

Table 1. Antimicrobial susceptibility of coagulase-negative Staphylococcus (CNS) ( $\mathrm{n}=34$ ) and coagulase-positive Staphylococcus (CPS) (n=22) isolates.

\begin{tabular}{|c|c|c|c|c|c|c|}
\hline \multirow{2}{*}{$\frac{\text { Antibiotics }}{\text { (Concentration) }}$} & \multicolumn{2}{|c|}{ CNS } & \multicolumn{2}{|c|}{ CPS } & \multicolumn{2}{|c|}{ Total (CNS+CPS) } \\
\hline & $\mathrm{R}$ & $\mathrm{S}$ & $\mathrm{R}$ & $S$ & $\mathrm{R}$ & $\mathrm{S}$ \\
\hline & n (\%) & n $(\%)$ & n $(\%)$ & n (\%) & n (\%) & n (\%) \\
\hline Vancomycin $(30 \mu \mathrm{g})$ & 0 & $34(100)$ & 0 & $22(100)$ & 0 & $56(100)$ \\
\hline Oxacillin $(1 \mu \mathrm{g})$ & $4(11.76)$ & $30(88.24)$ & $22(100)$ & 0 & $26(46.43)$ & $30(53.57)$ \\
\hline Chloramphenicol (30 $\mu \mathrm{g})$ & $3(8.82)$ & 31 (91.18) & 0 & $22(100)$ & $3(5.36)$ & $53(94.64)$ \\
\hline Tetracycline $(30 \mu \mathrm{g})$ & $13(38.24)$ & $21(61.76)$ & $22(100)$ & 0 & $35(62.5)$ & $21(37.5)$ \\
\hline Erythromycin $(15 \mu \mathrm{g})$ & $15(44.12)$ & $19(55.88)$ & $22(100)$ & 0 & $37(66.07)$ & 19 (33.93) \\
\hline Cefoxitin $(30 \mu \mathrm{g})$ & $6(17.65)$ & $28(82.35)$ & $22(100)$ & 0 & $28(50)$ & $28(50)$ \\
\hline Gentamicin $(10 \mu \mathrm{g})$ & 0 & $34(100)$ & 0 & $22(100)$ & 0 & $56(100)$ \\
\hline Ciprofloxacin $(5 \mu \mathrm{g})$ & 0 & $34(100)$ & 0 & $22(100)$ & 0 & $56(100)$ \\
\hline Ampicillin $(10 \mu \mathrm{g})$ & $12(35.29)$ & $22(64.71)$ & $22(100)$ & 0 & $34(60.71)$ & $22(39.29)$ \\
\hline Penicillin (10 I.U.) & $12(35.29)$ & $22(64.71)$ & $22(100)$ & 0 & $34(60.71)$ & $22(39.29)$ \\
\hline
\end{tabular}

n: number of isolates, R: resistant, S: susceptible. 
2011), similar to this study. Possible reasons for the negative findings may be that the bacterial level is below the detection limit of the cultural method.

In this study, antimicrobial resistance was very high among the isolates, unlike the study conducted in Sweden (Persson et al 2011). While penicillin and ampicillin resistance is more prevalent in S. aureus and CNS in other studies (Costa et al 2000, Pitkälä et al 2004, Tenhagen et al 2006, Kalmus et al 2011, Persson et al 2011, Ergün et al 2012), Huber et al (2011) and Zdolec et al (2016) detected higher erythromycin and tetracycline resistance in staphylococci isolates besides beta-lactam resistance, similar to this study. This may be due to the use of these antibiotics in an uncontrolled and unconscious manner.

In Italy, Virdis et al (2010) found that CNS isolated from milk samples of goats with subclinical mastitis showed more frequently resistance to ampicillin and kanamycin, unlike this study and Frey et al (2013). Frey et al (2013) determined both multidrug resistance and mecA gene in CNS from bovine mastitis milk, while Virdis et al (2010) and Persson et al (2011) didn't detect mecA gene in their isolates. In this study, the highest susceptibility against vancomycin, gentamicin, and ciprofloxacin was similar with Costa et al (2000), Persson et al (2011), Kalmus et al (2011), Ergün et al (2012).

Sawant et al (2009), Huber et al (2011), Sampimon et al (2011), and Waller et al (2011) reported that multidrug resistance and methicillin resistance gene mecA is now available in CNS strains. In the present study, mecA gene was not detected in any CNS, although some CNS isolates were phenotypically resistant to both oxacillin and cefoxitin. As defined by Sampimon et al (2011), phenotypic and genotypic antimicrobial resistance profiles of CNS can show difference.

\section{Conclusion}

As a result, $48.0 \%$ of the milk samples from the dairy cows with chronic recurrent mastitis were microbiologically positive for CPS and CNS. MRSA was detected in 7 (13.4\%) of the samples. All isolates were resistant to $70 \%$ of the tested antimicrobials. Therefore, such studies should be repeated regularly to better define the antimicrobial susceptibility of mastitis pathogens, which is very important for effective treatment of the disease. To prevent the spread of MRSA through the dairy food chain, milk from chronic recurrent mastitic cows should not be used as mixed with milk obtained from healthy cows.

\section{Acknowledgements}

A part of this study was orally presented at the International Congress on Food of Animal Origin (Turkish Republic of North Cyprus, 10-13 November 2016).

\section{References}

Bennett RW, Lancette GA, 1998. Staphylococcus aureus. Chapter 12. In FDA's Bacteriological Analytical Manual (8th ed.). (Revision A).

Brakstad OG, Aasbakk K, Maeland JA, 1992. Detection of Staphylococcus aureus by polymerase chain reaction amplification of the nuc gene. J Clin Microbiol, 30, 1654-1660.

Clinical and Laboratory Standards Institute (CLSI), 2015. Performance standards for antimicrobial susceptibility testing; twenty- fifth informational supplement. CLSI document. M100-S25, Wayne, PA.

Costa EO, Benites NR, Guerra JL, Melville PA, 2000. Antimicrobial susceptibility of Staphylococcus spp. isolated from mammary parenchymas of slaughtered dairy cows. J Vet Med, B47, 99-103.

Ergün Y, Aslantaş Ö, Kireçci E, Öztürk F, Ceylan A, Boyar Y, 2012. Antimicrobial susceptibility, presence of resistance genes and biofilm formation in coagulase negative

staphylococci isolated from subclinical sheep mastitis. Kafkas Univ Vet Fak Derg, 18, 449-456.

Frey Y, Rodriguez JP, Thomann A, Schwendener S, Perreten V, 2013. Genetic characterization of antimicrobial resistance in coagulase-negative staphylococci from bovine mastitis milk. J Dairy Sci, 96, 2247-2257.

Huber H, Ziegler D, Pflüger V, Vogel G, Zweifel C, Stephan R, 2011. Prevalence and characteristics of methicillin-resistant coagulase-negative staphylococci from livestock, chicken carcasses, bulk tank milk, minced meat, and contact persons. BMC Vet Res, 7, 1-7.

International Dairy Federation (IDF), 1985. Milk and Milk Products: Guidance on Sampling. International Dairy Federation, Standard 50B, Brussels, Belgium.

Kalmus P, Aasmäe B, Kärssin A, Orro T, Kask K, 2011. Udder pathogens and their resistance to antimicrobial agents in dairy cows in Estonia. Acta Vet Scand, 53, 1-7.

Keyvan E, Özdemir H, 2016. Occurrence, enterotoxigenic properties and antimicrobial resistance of Staphylococcus aureus on beef carcasses. Vet J Ankara Uni, 63, 17-23.

Martins A, Cunha MLRS, 2007. Methicillin resistance in Staphylococcus aureus and coagulase-negative staphylococci: Epidemiological and molecular aspects. Microbiol Immunol, 51, 787-795.

Mehrotra M, Wang G, Johnson WM, 2000. Multiplex PCR for detection of genes for Staphylococcus aureus enterotoxins, exfoliative toxins, toxic shock syndrome toxin 1 , and methicillin resistance. J Clin Microbiol, 38, 1032-1035.

Monday SR, Bohach GA, 1999. Use of multiplex PCR to detect classical and newly described pyrogenic toxin genes in staphylococcal isolates. J Clin Microbiol, 37, 3411-3414.

Persson Y, Nyman AJ, Grönlund-Andersson U, 2011. Etiology and antimicrobial susceptibility of udder pathogens from cases of subclinical mastitis in dairy cows in Sweden. Acta Vet Scand, 53, 1-8.

Pitkälä A, Haveri M, Pyörälä S, Myllys V, Honkanen-Buzalski T, 
2004. Bovine mastitis in Finland 2001-Prevalence, distribution of bacteria, and antimicrobial resistance. J Dairy Sci, 87, 2433-2441.

Sampimon OC, Lam TJGM, Mevius DJ, Schukken YH, Zadoks RN, 2011. Antimicrobial susceptibility of coagulase-negative staphylococci isolated from bovine milk samples. Vet Microbiol, 150, 173-179.

Sawant AA, Gillespie BE, Oliver SP, 2009. Antimicrobial susceptibility of coagulase-negative Staphylococcus species isolated from bovine milk. Vet Microbiol, 134, 73-81.

Taponen S, Pyörälä S, 2009. Coagulase-negative staphylococci as cause of bovine mastitis not so different from Staphylococcus aureus? Vet Microbiol, 134, 29-36.

Tenhagen BA, Köster G, Wallmann J, Heuwieser W, 2006. Pre- valence of mastitis pathogens and their resistance against antimicrobial agents in dairy cows in Brandenburg, Germany. J Dairy Sci, 89, 2542-2551.

Virdis S, Scarano C, Cossu F, Spanu V, Spanu C, De Santis EPL, 2010. Antibiotic resistance in Staphylococcus aureus and coagulase negative staphylococci isolated from goats with subclinical mastitis. Vet Med Int, 2010 (517060), 1-6.

Waller KP, Aspán A, Nyman A, Persson Y, Andersson UG, 2011. CNS species and antimicrobial resistance in clinical and subclinical bovine mastitis. Vet Microbiol 152, 112-116.

Zdolec N, Dobranić V, Butković I, Koturić A, Filipović I, Medvid V, 2016. Antimicrobial susceptibility of milk bacteria from healthy and drug-treated cow udder. Vet Arhiv, 86, 163-172. 